\title{
Strawberry genotypes with resistance to Tetranychus urticae mediated by leaf trichomes
}

\author{
Resistência de genótipos de morangueiro ao Tetranychus urticae mediada \\ por tricomas foliares
}

\author{
Juliano Tadeu Vilela de Resende ${ }^{1 *}(\mathbb{D})$, Renato Barros de Lima Filho ${ }^{(D)}$, Luana Karolline Ribeiro ${ }^{2}$ (D), \\ Jéssica Vanessa Wosniak Corrêa² (D), Cleber Daniel de Goes Maciel ${ }^{2}$ (D) Khamis Youssef $^{3}$ (i)
}

\author{
1 Universidade Estadual de Londrina/UEL, Departamento de Agronomia, Londrina, PR, Brasil \\ ¿Universidade Estadual do Centro-Oeste/UNICENTRO, Departamento de Agronomia, Guarapuava, PR, Brasil \\ ${ }^{3}$ Agricultural Researcher Center, Plant Pathology Research Institute, Giza, Egypt \\ ${ }^{*}$ Corresponding author: jvresende@uel.br \\ Received in March 23, 2020 and approved in June 26, 2020
}

\begin{abstract}
The two-spotted spider mite (Tetranychus urticae) is the main pest encountered in strawberry cultivation in protected environments, causing damage and increasing the cost of production associated with chemical control. Breeding programs are essential for obtaining new cultivars that are more tolerant to two-spotted spider mites. The objective was to evaluate whether the leaf trichomes mediatethe resistance of intraspecific strawberry hybrids to two-spotted spider mites. Preselected hybrids were subjected to infestation by two-spotted spider mites and evaluated via the no-choice assay and the travel test. Resistance was correlated with the density of trichomes, both glandular and non-glandular, present on the surface of the leaflets of strawberry genotypes. The results indicated that there is an influence of hybrids and cultivars on the behavior of the pest, allowing the verification of the existence of resistant genotypes (RVDA\#16, RVCS\#44 and Camino Real). These treatments resulted in low numbers of eggs deposited and hatched compared with the other treatments and shorter distances traveled by two-spotted spider mites on the surface of leaflets. It was also verified that the glandular trichomes presented a significant negative correlation with the average distance traveled by two-spotted spider mites on the surface of the leaf discs, indicating that these structures alter the behavior of these arthropods. Genotype resistance was associated with the presence of glandular trichomes. In addition to the superiority of the agronomic and postharvest attributes of the preselected hybrids (RVDA\#16 and RVCS\#44) identified in the previous selection efforts, they proved to be promising materials for achieving resistance to the spider mite, revealing important genotypes for use as cultivars and particularly as parents in breeding programs.
\end{abstract}

Index terms: Fragaria $x$ ananassa; intraspecific hybridization; antibiosis; antixenosis.

\section{RESUMO}

O ácaro rajado (Tetranychus urticae) é a principal praga do morangueiro em ambiente protegido, causando danos e aumentando os custos de produção com o controle químico. Em programas de melhoramento, é essecial que as novas cultivares sejam tolerantes ao ácaro. Assim, objetivou-se avaliar a resistência ao ácaro rajado de híbridos intraespecíficos, pré-selecionados, mediada por tricomas foliares. Híbridos pré-selecionados foram submetidos a presença do ácaro rajado e avaliados por meio do teste sem chance de escolha e caminhamento, na superfície do folíolo. A resistência ao ácaro foi correlacionada de forma significativa e com a densidade de tricomas glandularese não glandulares,na superfície abaxial dos folíolos dos genótipos.Os resultados evidenciam que há influência dos híbridos pré-selecionados e cultivares, no comportamento do ácaro rajado, permitindo, constatar a resistência dos genótipos RVDA\#16, RVCS\#44 e Camino Real. Esses tratamentos obtiveram menor número de ovos depositados e eclodidos, quando comparados aos demais e, também menores distâncias percorridas pelo ácaro rajado. Verificou-se ainda que os tricomas glandulares foram correlacionados significativa e negativamente com a distância média percorrida pelo ácaro rajado, na superfície dos discos foliares dos genótipos RVDA\#16, RVCS\#44 e Camino Real, indicando que essas estruturas alteram o comportamento do artrópode-praga. A resistência dos genótipos está associada a presença dos tricomas gladulares. Os híbridos pré-selecionados (RVDA\#16 e RVCS\#44), além da superioridade dos atributos agronômicos e de pós-colheita, identificados na seleção anterior, foram promissores para resistência ao ácaro rajado, consistindo em importante genótipo para ser utilizado como cultivar e, principalmente, como parental em programas de melhoramento genético.

Termos para indexação: Fragaria x ananassa; hibridação intraespecífica; antibiose; antixenose. 


\section{INTRODUCTION}

Strawberry (Fragaria x ananassa Duch.) shows high profitability and plays an important socioeconomic role in countries such as the United States, Mexico, Turkey, and Latin American countries such as Brazil and Chile (Biasio et al., 2015). However, pests and diseases are problems that limit the yield potential of cultivars, as they significantly impair the development of fruits (Van Leeuwen et al., 2015; Zhang et al., 2018). Among the pests attacking this crop, the two-spotted spider mite, Tetranychus urticae Koch (Acari: Tetranychidae), stands out as the main pest in protected environments and can reduce fruit production by up to $80 \%$ (Çobanoğlu; Güldali, 2017). The damage is caused by the form of feeding, since the mites break the cells of the epidermis through the introduction of their chelicera on the underside of the leaves to feed on the intracellular contents, thereby causing the death of the attacked cells (Bernardi et al., 2015; Gong et al., 2018).

The application of acaricides is the most widely used method for controlling spider mites (Van Leeuwen et al., 2010; Attia et al., 2013). However, the excessive application of these products is responsible for causing the development of populations that are resistant to acaricides (Grbić et al., 2011), reductions in natural enemies, the appearance of secondary pests and high levels of residues of phytosanitary products in fruits (Csányi et al., 2019). Thus, as an alternative to reduce the need for pesticides, varietal resistance is an important strategy within an integrated pest management (IPM) program. In addition to influencing the behavior of the arthropod pest through plant characteristics, this tool can be used in parallel with other control methods without any restrictions (Fahim; Momen; Saiedy, 2020).

In strawberry plants, both constitutive and inductive defense mechanisms protect plants against pest attack (Karlec et al., 2017). In constitutive defense, the plant does not depend on the presence or action of pests, and its resistance is expressed continuously. In contrast, the plant only expresses induced defense when injury occurs, and this type of resistance directly affect herbivores or natural enemies (Smith; Clement, 2012; Moreira et al., 2018). Trichomes are important constitutive defense mechanisms; there are two types of trichomes described in strawberry plants: glandular and non-glandular trichomes (Benatto; Penteado; Zawadneak, 2019; Hata et al., 2020). The resistance of cultivars to spider mites is related to the density of the glandular trichomes, which store substances hindering the herbivore's walking and feeding (Oliveira et al., 2018; Bac-Molenaar et al., 2019).
The identification of plants with greater resistance to pest arthropods is extremely important for plant breeding programs; therefore, evaluating and understanding their behavior is essential (Gong et al., 2018). However, the resistance of different genotypes is not normally evaluated, and in the main strawberry breeding programs, productive aspects are the key parameters for the selection of plants. Reconciling these aspects makes it possible to select resistant or pest-tolerant plants, facilitating management in the production field.

Thus, the objective of this study was to evaluate preselected strawberry genotypes regarding their resistance to spider mites associated with the presence of leaf trichomes.

\section{MATERIAL AND METHODS}

\section{Experimental material}

Twelve hybrid populations were obtained from crosses between the Aromas, Camarosa, Dover, Festival, Oso Grande, Sweet Charlie and Milsei Tudla cultivars. The seedlings obtained from each population were divided and evaluated under the climatic conditions of the south of the state of Minas Gerais and the south-central state of Paraná. Genotypes selected based on agronomic and postharvest characteristics at both locations were used to design the composition of treatments. The preselected strawberry hybrids used in the trial, RVFS\#07 (Festival Florida $x$ Sweet Charlie), RVDA\#16 (Camarosa x Aromas) and RVCS\#44 (Camarosa $x$ Sweet Charlie), came from the UNICENTRO/UEL/UFLA breeding program (Galvão et al., 2017; Barth et al., 2019; Barth et al., 2020), maintained at the Germplasm Bank of UEL/UNICENTRO. In addition to the hybrids, the commercial cultivars Camarosa, Camino Real (short photoperiod cultivars), Albion, and Monterey (neutral photoperiod cultivars) served as check treatments.

The research was carried out at the Entomology Laboratory of Midwestern Parana State University, located in Guarapuava, $\mathrm{PR}\left(25^{\circ} 38^{\prime} \mathrm{S}\right.$ and $51^{\circ} 48^{\prime} \mathrm{W}$, with an altitude of 1100 meters), from September to November 2019.

The plants were grown in a greenhouse in pots of $5 \mathrm{dm}^{3}$ containing subsurface soil corrected to $70 \%$ of base saturation. Forty-five days before the transplantation of the seedlings, they were fertilized with $25 \mathrm{~g}$ of $04-14-08$ (N-P-K) fertilizer. During the development of the plants, necessary cultural treatments were carried out without the use of phytosanitary products, which could interfere with the tests. The indoor temperature of the greenhouse was 
maintained at $25 \pm 3{ }^{\circ} \mathrm{C}$ with a relative humidity of $70 \pm$ $4 \%$ and a photophase of $12 \mathrm{~h}$. The plants were irrigated with micro drippers according to the plant requirements.

\section{Identification and quantification of trichomes}

To carry out the identification and quantification of trichomes, young leaflets were collected and expanded from the median portion of plants of each genotype aged 45-60 days. A sample with an area of $3 \mathrm{~mm}^{2}$ was taken from each leaflet. The analyses were carried out with four replications, with the samples fixed on carbon tape over the sample holder compartment, by using a scanning electron microscope (SEM), model VEGA3 TESCAN, at a 100-fold magnification. Non-glandular and glandular trichomes were identified and quantified on the leaflet's abaxial surface (Figure 1).

\section{Resistance tests}

To verify the existence of resistance to $T$. urticae, behavioral tests were preferably carried out in no-choice assays and walking tests. The two-spotted spider mites used in the experiments were obtained from controlled breeding performed in the laboratory and were maintained on bean leaves (Phaseolus vulgaris L.), with the objective of using two-spotted spider mites of the same age.

\section{No-choice assay}

The no-choice assay was performed in arenas mounted on Petri dishes (50 $\mathrm{mm}$ diameter), which were filled with a sponge superimposed upon moistened cotton. Each experimental unit involved three strawberry leaf discs of $18 \mathrm{~mm}$ in diameter, and on each one, a female of T. urticae was released. After 24 hours, the females were removed from the disks, and the number of deposited eggs was quantified. The hatching of eggs was evaluated at 96 and 120 hours after female release. The experiment was carried out in a completely randomized design with 8 replications, in an air-conditioned room with a 12 -hour photophase and a controlled temperature of $25 \pm 2{ }^{\circ} \mathrm{C}$.

\section{Mite walking bioassay}

For the walking experiment, the methodology used was proposed by Weston and Snyder (1990). A leaflet of each genotype was fixed with a metal thumbtack in the center of a sulfite sheet in an expanded polystyrene plate. Ten females of $T$. urticae were released on the thumbtack, and at 20, 40 and 60 minutes after release, the distances traveled by the mites (millimeters) on the surface of each leaflet were measured with the aid of a graduated ruler.

For this evaluation, the distance traveled by the two-spotted spider mites that remained on the thumbtack (without moving) was considered zero, while for the mites that left the surface of the leaflet, the distance between the center of the thumbtack and the greatest distance toward the tip of the leaflet was considered. The experiment was conducted in a randomized block design, with five replications, in an air-conditioned environment with a temperature of $20 \pm 3{ }^{\circ} \mathrm{C}$ and a relative humidity of $70 \pm 4 \%$.

\section{Statistical analysis}

Data were tested for normality and homogeneity of the residuals using the Shapiro-Wilk and Hartley tests, respectively. When the $\mathrm{F}$ test was significant, the means were subjected to the Tukey test at the 5\% significance level and analyzed using the Sisvar ${ }^{\circledR}$ statistical program (Ferreira, 2011). Pearson's correlations were estimated using SPSS ${ }^{\circledR} 22$ software (IBM Corp, 2013).

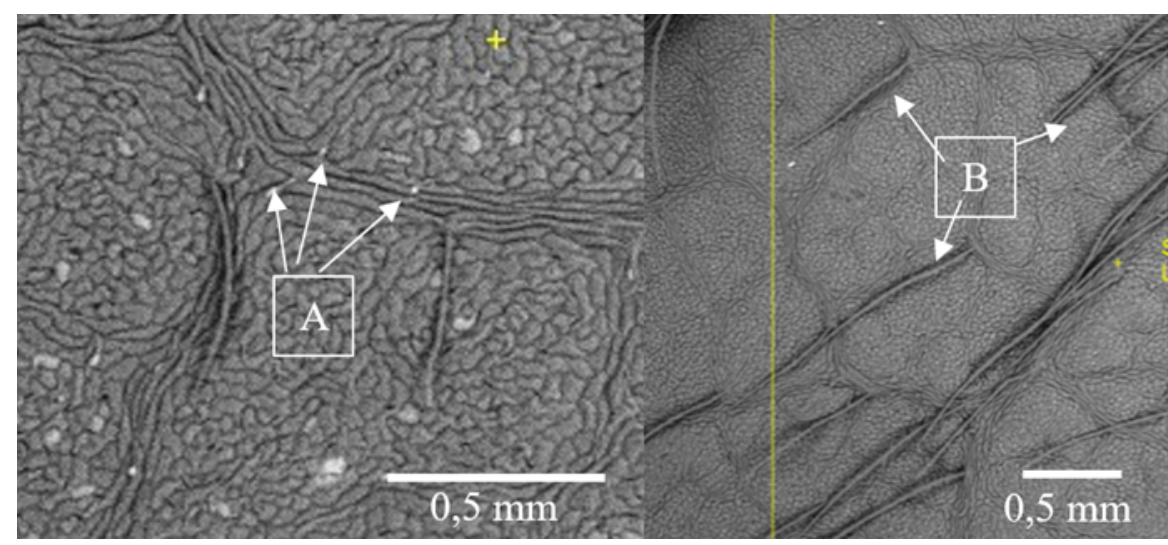

Figure 1: Trichomes present on strawberry leaflets. A- glandular trichomes; B- non-glandular trichomes. 


\section{RESULTS AND DISCUSSION}

\section{Identification and quantification of trichomes}

The obtained results indicated that there was an influence of the preselected hybrids and cultivars on the behavior of the spider mites, allowing us to verify the existence of superior genotypes, such as the hybrids RVDA\#16 and \# RVCS\#44 and the cultivar Camino Real, which showed greater resistance. The results indicated that spider mite resistance was related to the mechanisms of the antibiosis types and not preference (Karlec et al., 2017).

In the samples of the leaflets used in the treatments, the trichomes of the glandular and non-glandular types were identified. A significant difference in the density of trichomes present on the abaxial surface of the leaflets was observed between the genotypes (Table 1).

Table 1: Average number of glandular, non-glandular and total trichomes observed on strawberry leaflet $\left(3 \mathrm{~mm}^{2}\right.$ ) from the UNICENTRO/UEL/UFLA breeding program.

\begin{tabular}{cccc}
\hline Genotype & $\begin{array}{c}\text { Glandular } \\
\text { trichomes }\end{array}$ & $\begin{array}{c}\text { Non-glandular } \\
\text { trichomes }\end{array}$ & $\begin{array}{c}\text { Total } \\
\text { trichomes }\end{array}$ \\
\hline RVFS\#07 & $12.0 f^{*}$ & $28.00 \mathrm{bc}$ & $40.00 \mathrm{c}^{*}$ \\
RVDA\#16 & $14.75 \mathrm{e}$ & $33.70 \mathrm{ab}$ & $48.50 \mathrm{~b}$ \\
RVCS\#44 & $27.25 \mathrm{~b}$ & $20.00 \mathrm{~d}$ & $47.25 \mathrm{~b}$ \\
Albion & $23.00 \mathrm{c}$ & $14.75 \mathrm{~d}$ & $37.75 \mathrm{c}$ \\
Camarosa & $20.00 \mathrm{~d}$ & $38.00 \mathrm{a}$ & $58.00 \mathrm{a}$ \\
Camino Real & $49.00 \mathrm{a}$ & $14.25 \mathrm{~d}$ & $63.25 \mathrm{a}$ \\
Monterey & $10.50 \mathrm{f}$ & $26.25 \mathrm{c}$ & $36.75 \mathrm{c}$ \\
CV (\%) & 4.37 & 10.31 & 5.36 \\
\hline *Averages followed by the same letter do not differ by Tukey's \\
test at 5\% probability of confidence.
\end{tabular}

The highest number of glandular trichomes was found in the cultivar Camino Real $\left(49.003 \mathrm{~mm}^{-2}\right)$, followed by the hybrid RVCS\#44 $\left(27.253 \mathrm{~mm}^{-2}\right)$. The cultivar Camarosa $\left(38.003 \mathrm{~mm}^{-2}\right)$ and the hybrid RVDA\#16 (33.70 $3 \mathrm{~mm}^{-2}$ ) showed the greatest numbers of non-glandular trichomes. In relation to the total number of trichomes (glandular and non-glandular), the cultivars Camino Real $\left(63.253 \mathrm{~mm}^{-2}\right)$ and Camarosa $\left(58.003 \mathrm{~mm}^{-2}\right)$ stood out among the other evaluated genotypes. The hybrids RVDA\#16 and RVCS\#44 also stood out in terms of the evaluated trait (Figure 2), with relatively high values for the number of total trichomes. The differences in the density of the trichomes present in the genotypes, both non-glandular and glandular, may have influenced the behavior of the two-spotted spider mites.

The density of total trichomes had no influence on the results regarding resistance, as demonstrated by the fact that even though the cultivar Camarosa presented a higher concentration of total trichomes, it was more preferred than Camino Real, indicating that a higher density of glandular trichomes confers resistance in the genotype more efficiently. The glandular trichomes and non-glandular trichomes present on strawberry leaflets are promoters of two-spotted spider mite resistance through constitutive mechanisms (Benatto; Penteado; Zawadneak, 2019; Hata et al., 2020). Resistance in strawberry plants is attributed to constitutive and inductive defense mechanisms that protect against pest attack (Kalec et al., 2017). Research observations show that the defense mechanisms associated with glandular and non-glandular trichomes can largely be classified as constitutive and do not depend on the presence of pests on the plants; that is, this type of resistance is expressed continuously.

In general, plants with higher trichome densities, especially for glandular trichomes, exhibit greater resistance to pests than plants with a low density of leaf trichomes. Benatto et al. (2018) analyzed the density of trichomes on Albion and Aromas strawberry cultivars and found higher numbers of trichomes compared to the Camarosa and San Andreas cultivars. In the present work, the density of trichomes in 'Camarosa' was higher than that observed in 'Albion', and it can be inferred that this characteristic can be highly influenced by the environment. However, Karlec et al. (2017) reported that the Camarosa cultivar may exhibit antibiosis-type resistance to the two-spotted mite, whose preferences regarding feeding, development and oviposition differed from the results obtained in this research.

\section{No-choice assay}

The no-choice assay showed significant differences in the number of eggs deposited on the leaflets by the twospotted spider mite females at 24 hours after release. A nonpreference for oviposition on the commercial materials Albion and Camino Real and the hybrids RVDA\#16 and RVCS\#44 was evident, showing differences in relation to the other tested materials (Table 2).

No difference in egg hatching was observed $96 \mathrm{~h}$ after female release on the genotype leaflets. However, there was a difference in the hatching of eggs under the evaluated treatments at $120 \mathrm{~h}$ after the release of the females on the leaflets, with fewer eggs hatching on the cultivars Albion and Camino Real, and the hybrids RVDA\#16 and RVCS\#44 (Table 2). 


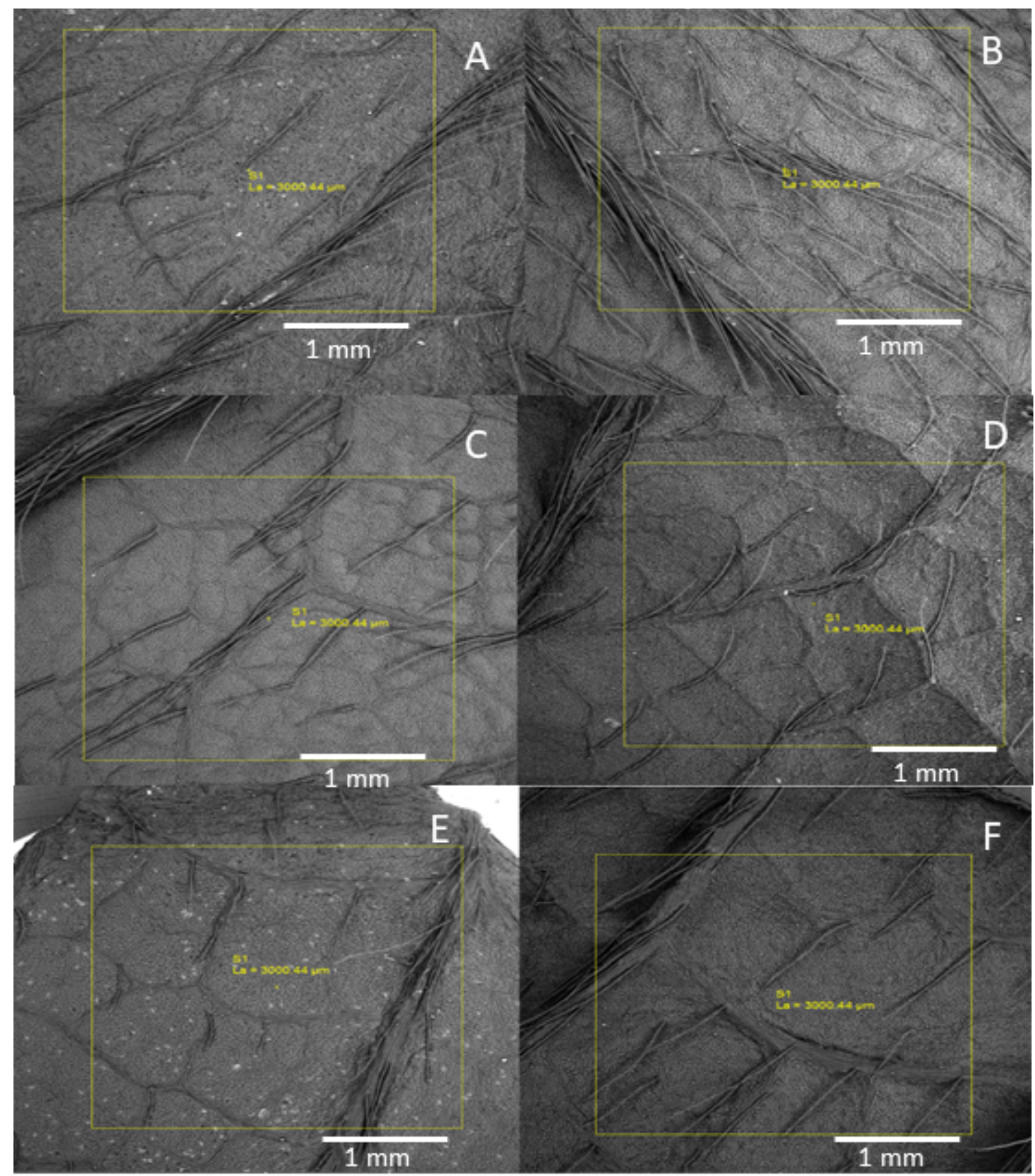

Figure 2: Images of the sampling area with trichomes on the abaxial surface of the leaflets of hybrids RVFS\#07 (A), RVDA\#16 (B), and RVCS\#44 (C), preselected from the UNICENTRO/UEL/UFLA breeding program, and the cultivars Albion (D), Camarosa (E) and Camino Real (F).

The highest number of eggs deposited on the leaflets was observed on the cultivars Monterey and Camarosa and the hybrid RVFS\#07, differing from the cultivars Albion and Camino Real and the hybrids RVDA\#16 and RVCS\#44, which presented the lowest values for oviposition. The percentages of hatched eggs on the cultivar Camino Real $(54.65 \%)$ and the hybrid RVDA\#16 (56.83\%) were lower than those observed on the cultivars Albion (90.99\%), Camarosa $(90.86 \%)$ and Monterey (97.75\%) (Table 2). 
Table 2: Average number of eggs deposited 24 hours after release of females on the surface of leaf discs and hatched 96 and 120 hours after release of T. urticae females in strawberry genotypes.

\begin{tabular}{cccccc}
\hline \multirow{2}{*}{ Genotype } & \multirow{2}{*}{$N^{\circ}$ eggs } & \multicolumn{2}{c}{96 hours } & \multicolumn{2}{c}{120 hours } \\
\cline { 3 - 6 } & & Hatched eggs & Hatched eggs (\%) & Hatched eggs & Hatched eggs (\%) \\
\hline RVFS\#07 & $9.75 b^{*}$ & $0.50^{\text {ns }}$ & 6.45 & $6.50 b^{*}$ & 83.87 \\
RVDA\#16 & $5.66 \mathrm{a}$ & 0.91 & 24.86 & $2.08 \mathrm{a}$ & 56.83 \\
RVCS\#44 & $4.25 \mathrm{a}$ & 1.00 & 23.53 & $3.16 \mathrm{a}$ & 74.35 \\
Albion & $5.33 \mathrm{a}$ & 0.75 & 26.60 & $3.66 \mathrm{a}$ & 90.99 \\
Camarosa & $8.33 \mathrm{~b}$ & 0.75 & 10.23 & $6.66 \mathrm{~b}$ & 90.86 \\
Camino Real & $3.41 \mathrm{a}$ & 1.00 & 22.68 & $2.41 \mathrm{a}$ & 54.65 \\
Monterey & $13.00 \mathrm{~b}$ & 0.66 & 8.25 & $7.96 \mathrm{~b}$ & 97.75 \\
CV (\%) & 11.38 & 62.31 & - & 17.11 & - \\
F & 36.02 & 0.42 & - & 29.32 & - \\
\hline
\end{tabular}

${ }^{\mathrm{n}} \mathrm{do}$ not differ statistically by the f test. *averages followed by the same letter do not differ by Tukey's test at 5\% probability.

\section{Mite walking test}

In the evaluation of mite walking on the strawberry leaflets, differences were observed between the genotypes at all times of evaluation, particularly at 20,40 and 60 minutes after the release of the two-spotted spider mites on the thumbtacks. It was also possible to verify an increase in the distance traveled, as the evaluations occurred at 20, 40, and 60 minutes (Table 3). In all assessments, the least displacement of the two-spotted spider mites was observed on the surfaces of the leaflets of the Camino Real cultivar and the RVDA\#16 and RVCS\#44 hybrids, differing from the other treatments. When the path on the commercial cultivars Albion, Camarosa and Monterey was evaluated, greater distances traveled by the two-spotted spider mites were observed, demonstrating less repellency of the arthropod (Table 3).

These treatments resulted in a smaller number of eggs deposited and hatched compared with other treatments evaluated (Table 2) and shorter distances covered by the two-spotted spider mites on the leaflets (Table 3). Figueiredo et al. (2013) reported a shorter path of the mites on the Camino Real cultivar, indicating high resistance to this two-spotted spider mite in relation to other cultivars tested, which corroborates the present research.

According to Peterson, Varella and Higley (2017), chemical, physical and morphological characteristics of plants influence the oviposition of arthropods. Thus, the presence of nutrients, volatile repellents or attractive compounds and the type and density of non-glandular and glandular trichomes on the leaf surface can interfere with the preference of the pest to the strawberry plant (Van Den Boom; Van Beek; Dicke, 2003; Hoy, 2016).
Table 3: Average of the distance traveled by the two-spoted spider mites on the walking bioassay in different strawberry genotypes.

\begin{tabular}{cccc}
\hline Genotype & $\begin{array}{c}20 \text { minutes } \\
(\mathrm{mm})\end{array}$ & $\begin{array}{c}40 \text { minutes } \\
(\mathrm{mm})\end{array}$ & $\begin{array}{c}60 \text { minutes } \\
(\mathrm{mm})\end{array}$ \\
\hline RVFS\#07 & $28.47 \mathrm{~b}^{*}$ & $29.20 \mathrm{~cd}^{*}$ & $31.37 \mathrm{bc}$ \\
RVDA\#16 & $16.57 \mathrm{a}$ & $19.20 \mathrm{a}$ & $21.17 \mathrm{a}$ \\
RVCS\#44 & $17.42 \mathrm{a}$ & $20.85 \mathrm{ab}$ & $23.75 \mathrm{a}$ \\
Albion & $30.27 \mathrm{bc}$ & $35.27 \mathrm{de}$ & $38.10 \mathrm{def}$ \\
Camarosa & $33.92 \mathrm{~cd}$ & $37.22 \mathrm{de}$ & $38.90 \mathrm{de}$ \\
Camino Real & $15.9 \mathrm{a}$ & $18.25 \mathrm{a}$ & $20.52 \mathrm{a}$ \\
Monterey & $36.92 \mathrm{~d}$ & $41.07 \mathrm{e}$ & $42.67 \mathrm{ef}$ \\
CV (\%) & 10.77 & 10.36 & 8.58 \\
F & 24.99 & 20.41 & 23.91 \\
\hline
\end{tabular}

*Averages followed by the same letter do not differ by Tukey's test at $5 \%$ probability of confidence.

Smaller numbers of eggs were found on the leaflets of the hybrids RVDA\#16 (5.66) and RVCS\#44 (4.25) and the cultivars Albion (5.33) and Camino Real (3.41), and lower percentages of hatched eggs were found onRVDA\#16 (56.83\%) and 'Camino Real' (54.65\%), indicating the presence of some factor affecting the behavior of two-spotted spider mites on these materials. When verifying the correlation between trichomes and the variables analyzed in the no-choice behavioral assay, it was found that glandular trichomes negatively influenced the number of eggs that were deposited and hatched 120 hours after the release of the two-spotted spider mite on the surface of the leaflets. This result 
presumably indicates that there are mechanisms of resistance of the antixenosis and antibiosis types affecting the interrelation ships between the herbivore and the strawberry genotypes.

The walking test allowed us to further verify the locomotion of the two-spotted spider mites on the surfaces of the leaflets of the cultivars Albion, Camarosa and Monterey, indicating less resistance to the arthropod. In addition, Camarosa and Monterey together with the RVFS\#07 hybrid exhibited high numbers of eggs deposited on the surface of the leaflets. Other studies also report the existence of differences between strawberry genotypes regarding susceptibility to the two-spotted spider mite (Monteiro et al., 2014; González-Domínguez et al., 2015).

It was also found that the glandular trichomes presented a significant negative correlation with the average distance covered by the two-spotted spider mite in the evaluations performed at 40 and 60 minutes after the release of the pest on the surface of the leaf discs of the evaluated genotypes (Table 4), indicating that these structures affect the behavior of the arthropod.

When the results obtained in the behavioral experiments were correlated with the presence of trichomes on strawberry leaflets, it was observed that the presence of glandular trichomes showed a negative correlation with the number of eggs deposited and hatched 120 hours after the release of the females. In the travel of the two-spotted spider mite, a negative influence was observed for all assessment times, but it was significant only at 60 minutes. The presence of glandular trichomes exhibited a negative correlation for the analyzed variables. When all trichomes were considered, it was found that the number of hatched eggs and the percentage after 120 hours of female release presented a negative correlation with these structures.
(Hata et al., 2020), found a significant and negative correlation between the incidence of Neopamera bilobata Say (Hemiptera: Rhyparochromidae) in strawberry and the density of trichomes on pseudo fruits. A negative correlation was also found between the density of glandular trichomes on tomato plants and the preference of T. evansi for oviposition (Savi et al., 2019). Lucini et al. (2015) and Maciel et al. (2018) showed that the density of glandular trichomes on tomato presents a significant negative correlation with the behavior (antixenosis and antibiosis) of pest arthropods, including the two-spotted spider mite.

According to Mathey et al. (2017), the diversity of environments contributes to the occurrence of genotype $x$ environment (GxE) interactions, which in addition to affecting the development of strawberry plants and productivity, also interferes with the physical-chemical characteristics of fruits and plant morphology (Figueiredo et al., 2013; Samykanno; Pang; Marriott, 2013; Palmieri et al., 2017). Thus, it can be inferred that among the tested genotypes, the hybrids RVDA\#16 and RVCS\#44 present high resistance to two-spotted spider mites, together with the cultivar Camino Real.

The hybrids significantly affected the walking and oviposition of the spider mite, showing that for the goal of achieving resistance to the mite, the use of these hybrids as future cultivars can be considered. Taking that into consideration, they were selected because of showing excellent productive and postharvest performance (Galvão et al., 2017; Barth et al., 2019; Barth et al., 2020). Nevertheless, it is necessary to recommend the continuation of the breeding program, considering that these hybrids can be used as parents in future generations. Furthermore, there is still a need to conduct studies to better elucidate the resistance/tolerance mechanisms involved.

Table 4: Correlations between the variables analyzed in the behavioral experiments and trichomes of strawberry leaflets.

\begin{tabular}{ccccccccc}
\hline & NE24 & EH96 & EH96 (\%) & EH120 & EH120 (\%) & $20^{\prime}$ & $40^{\prime}$ & $60^{\prime}$ \\
\hline GT & $-0.75^{*}$ & 0.05 & -0.19 & $-0.89^{*}$ & $-0.69^{*}$ & -0.30 & $-0.45^{*}$ & $-0.54^{*}$ \\
NGT & $0.48^{*}$ & 0.06 & $0.48^{*}$ & 0.39 & 0.17 & 0.2 & -0.03 & 0.07 \\
TT & -0.23 & 0.06 & 0.14 & $-0.47^{*}$ & $-0.6^{*}$ & -0.1 & -0.23 & 0.26 \\
\hline
\end{tabular}

* Pearson's correlation, significant by F test at 5\% probability. NGT-Non-glandular trichomes; GT-glandular trichomes; TTTotal trichomes; No-choice behavioral experiment: NE24 (Average number of eggs deposited after 24 hours); EH96 (Eggs hatched after 96 hours); \% EH96 (Percentage of eggs hatched after 96 hours); EH120 (Eggs hatched after 120 hours); \% EH120 (Percentage of eggs hatched after 120 hours); Walking experiment: 20' (Evaluation at 20 minutes); 40 ' (Evaluation at 40 minutes); 60 ' (Evaluated at 60 minutes). 


\section{CONCLUSIONS}

The density of glandular and non-glandular trichomes contributed to greater resistance of the strawberry genotypes to the two-spotted spider mite, decreasing its oviposition and hatching rates and walking on the leaf surface. The preselected RVDA\# 16 and RVCS \# 44 hybrids and the Camino Real cultivar were the most resistant genotypes to the studied mite.

\section{ACKNOWLEDGMENTS}

The authors are grateful to Support Program for Centers of Excellence (Pronex - FA/CNPq) for the Improvement of Higher Education Personnel (CAPES Finance).

\section{REFERENCES}

ATTIA, S. et al. A review of the major biological approaches to control the worldwide pest Tetranychus urticae (Acari: Tetranychidae) with special reference to natural pesticides. Journal of Pest Science, 86(3):361-386, 2013.

BAC-MOLENAAR, J. A. et al. Trichome independent resistance against western flower thrips in tomato. Plant Cell Physiology, 60(5):1011-1024, 2019.

BARTH, E. et al. Yield and quality of strawberry hybrids under subtropical conditions. Genetics and Molecular Research, 18(2):GMR18156, 2019.

BARTH, E. et al. Selection of experimental hybrids of strawberry using multivariate analysis. Agronomy, 10(4):598, 2020.

BENATTO, A. et al. Influence of trichomes in strawberry cultivars on the feeding behavior of Chaetosiphon fragaefolii (Cockerell) (Hemiptera: Aphididae). Neotropical Entomology, 47(4):569-576, 2018.

BENATTO, A.; PENTEADO, S.; ZAWADNEAK, M. Performance of Chaetosiphon fragaefolii (Hemiptera: Aphididae) in different strawberry cultivars. Neotropical Entomology, 48(4):692698, 2019.

BERNARDI, D. et al. Guia para a identificação e monitoramento de pragas e seus inimigos naturais em morangueiro. Embrapa Uva e Vinho-Livro científico, 2015. 49p.

BIASIO, R. et al. Calculation of cost and profitability of strawberries in a rural property located in Flores da Cunha/ RS. Custos e Agronegocio, 11(1):1-23, 2015.

ÇOBANOĞLU, S.; GÜLDALI, B. Plant parasitic and predatory mites (Acari: Tetranychidae, Phytoseiidae) and population density fluctuation of two-spotted spider mite (Tetranychus urticae Koch) on strawberry in the Mersin province of Turkey. Journal of Zoological Sciences, 5(2):57-67, 2017.

CSÁNYI, K. et al. Potential environmental impacts of powders of agricultural origin, with particular regard to the effects of pesticide, Southern Hungary. Geophysical Research Abstracts, 21(1):1-1, 2019.

FAHIM, S. F.; MOMEN, F. M.; EL-SAIEDY, E. S. M. Life table parameters of Tetranychus urticae (Trombidiformes: Tetranychidae) on four strawberry cultivars. Persian Journal of Acarology, 9(1):43-56, 2020.

FERREIRA, D. F. Sisvar: A computer statistical analysis system. Ciência e Agrotecnologia, 35(6):1039-1042, 2011.

FIGUEIREDO, A. S. T. et al. The role of glandular and nonglandular trichomes in the negative interactions between strawberry cultivars and spider mite. Arthropod-Plant Interactions, 7(1):53-58, 2013.

GALVÃO, A. G. et al. Breeding new improved clones for strawberry production in Brazil. Acta Scientiarum. Agronomy, 39(2):149-155, 2017.

GONG, Y. J. et al. Preference and performance of the two-spotted spider mite Tetranychus urticae (Acari: Tetranychidae) on strawberry cultivars. Experimental and Applied Acarology, 76(2):185-196, 2018.

GONZÁLEZ-DOMÍNGUEZ, S. et al. Variability in damage caused by the mite Tetranychus urticae (Trombidiformes: Tetranychidae) Koch on three varieties of strawberry. Journal of Economic Entomology, 108(3):1371-1380, 2015.

GRBIĆ, M. et al. The genome of Tetranychus urticae reveals herbivorous pest adaptations. Nature, 479(7374):487492, 2011.

HATA, F. T. et al. Neopamera bilobata Say (Hemiptera: Rhyparochromidae) habit and density on strawberry cultivars. Phytoparasitica, 48:183-190, 2020.

IBM Corp. Released. IBM SPSS Statistics for Windows, Version 22.0. Armonk, NY: 2013.

HOY, M. A. Agricultural Acarology: Introduction to integrated mite management. CRC press: Boca Raton. 2016. 410p.

KARLEC, F. et al. Development of Tetranychus urticae Koch (Acari: Tetranychidae) in different strawberry cultivars. Revista Brasileira de Fruticultura, 39(1):1-8, 2017. 
LUCINI, T. et al. Acylsugar and the role of trichomes in tomato genotypes resistance to Tetranychus urticae. ArthropodPlant Interactions, 9(1):45-53, 2015.

MACIEL, G. M. et al. Tomato genotypes with determinate growth and high acylsugar content presenting resistance to spider mite. Crop Breeding and Applied Biotechnology, 18(1):1-8, 2018.

MATHEY, M. M. et al. Genotype by environment interactions and combining ability for strawberry families grown in diverse environments. Euphytica, 213(5):112, 2017.

MONTEIRO, L. et al. Biology of the two-spotted spider mite on strawberry plants. Neotropical Entomology, 43(2):183188, 2014.

MOREIRA, X. et al. Plant domestication decreases both constitutive and induced chemical defences by direct selection against defensive traits. Scientific Reports, 8(1): 1-11, 2018.

OLIVEIRA, J. R. F. et al. Trichomes and allelochemicals in tomato genotypes have antagonistic effects upon behavior and biology of Tetranychus urticae. Frontiers in Plant Science, 9(1):1132, 2018.

PALMIERI, L. et al. Genotypebyenvironment effect on bioactive compounds in strawberry (Fragaria $\mathrm{x}$ ananassa Duch.). Journal of the Science of Food Agriculture, 97(12):41804189, 2017.

PETERSON, R. K.; VARELLA, A. C.; HIGLEY, L. G. Tolerance: The forgotten child of plant resistance. PeerJ, 5(1):1-16, 2017.

SAMYKANNO, K.; PANG, E.; MARRIOTT, P. J. Chemical characterisation of two Australian-grown strawberry varieties by using comprehensive two-dimensional gas chromatography-mass spectrometry. Food Chemistry, 141(3):1997-2005, 2013.

SAVI, P. et al. Impact of leaflet trichomes on settlement and oviposition of Tetranychus evansi (Acari: Tetranychidae) in African and South American tomatoes. Systematic and Applied Acarology, 24(12):2559-2576, 2019.

SMITH, C. M.; CLEMENT, S. L. Molecular bases of plant resistance to arthropods. Annual Review of Entomology, 57(1):309-328, 2012.

VAN DEN BOOM, C.; VAN BEEK, T.; DICKE, M. Differences among plant species in acceptance by the spider mite Tetranychus urticae Koch. Journal of Applied Entomology, 127(3):177183, 2003.

VAN LEEUWEN, T. et al. The economic importance of acaricides in the control of phytophagous mites and an update on recent acaricide mode of action research. Pesticide Biochemistry and Physiology, 121:12-21, 2015.

VAN LEEUWEN, T. et al. Acaricide resistance mechanisms in the two-spotted spider mite Tetranychus urticae and other important Acari: A review. Insect Biochemistry and Molecular Biology, 40(8):563-572, 2010.

WESTON, P. A.; SNYDER, J. C. Thumbtack bioassay: A quick method for measuring plant resistance to twospotted spider mites (Acari: Tetranychidae). Journal of Economic Entomology, 83(2):500-504, 1990.

ZHANG, H. et al. Recent developments in the enhancement of some postharvest biocontrol agents with unconventional chemicals compounds. Trends in Food Science Technology, 78:180-187, 2018. 